\title{
HISTORY OF UZBEK FOLK INSTRUMENTS
}

\author{
Feruza Kudrat Kizi Rakhmatova
}

Student, Namangan State University, Uzbekistan

\section{ABSTRACT}

The musical instruments reflect the national characteristics, traditions, customs and values of each nation, from which the sound is derived. Performing arts in musical instruments as a means of glorifying the spirituality of mankind is the responsibility of folk art, and from time immemorial has been formed and developed among the masses. The national instruments are constantly being perfected by skilled musicians and are distinguished by their vibrancy, musicality and melody. As musical instruments have become more and more in demand throughout history, so has the attention paid to their educational and pedagogical aspects.

KEYWORDS: - Status, genre, song, work, music, sunray, rhythm, form, style, instrument, art.

\section{INTRODUCTION}

Folk instruments have appeared in the distant past. It is believed that the first musical instruments were born in the XIII millennium BC. In the history of the family of musical instruments, percussion instruments first appeared. The main reason for this is the creative product of the labor of the most primitive people. Early primitive chambers tried to capture prey using a variety of hunting methods, even in the grief of feeding the animals. He left the log of the tree on top of the dried skin of the animals. The skin hardened from the scorching heat. The next time people came, they tried hard to get the skin, but they couldn't. Then when he struck the type with his hand or with a stick or a stick, it made a loud and pleasant sound, and it was later called a hurricane. Then came the noisy instruments, with the performers applauding and emphasizing the rhythm, increasing the impact of the noisy instruments. The applause of the female performers created a unique, unique beauty. In such labor processes, people's minds were naturally occupied with melody, melody, song. As a result of fruitful labor, songs began to emerge, and they were gradually passed from mouth to mouth, from father to son, from mother to daughter, and took a place in people's hearts for a lifetime.[1]

In the heart of ancient oriental culture, Uzbek folk instruments were formed. They have retained their distinctive features, the tone of sound, over the centuries of development. Thus dust, nay, surnay, tanbur, dutor, rubob, gijjak, kobiz came to us in traditional forms. 
CURRENT RESEARCH JOURNAL OF PEDAGOGICS 2(12): 98-105,

December 2021 DOI: https://doi.org/10.37547/pedagogics-crjp-02-12-20

ISSN 2767-3278

(C)2021 Master Journals

\section{Crossref do) 8 Google}

Accepted 18 $8^{\text {th }}$ December, 2021 \& Published 23 th December, 2021

During the period of slavery, there were Marakand, Nisa, Toprakkala, Termez and other cities. During the excavations in the territory of these cities were found artifacts, images of various instruments. Slavery was an important stage in the development of the culture of the peoples of Central Asia. As folk music grew, so did the instruments.

Archaeological expeditions in the 30s and 40s of the twentieth century (led by S.L. Tolstov, V.A. Vyatkin, M.B. Masson and others) provided valuable information. The found cultural monuments depict various musical instruments: tanbur, rubab-shaped instruments, kanun, ud, nay, surnay, karnay, circular instruments.[2]

Folk instruments have become an integral part of the life and work of the people of Central Asia. Accompanied by instruments, songs, games and melodies are performed at large ceremonies, family and seasonal celebrations. The holidays were more associated with the seasons. Seasonal holidays such as Navruz, Lola Sayli, Harvest Holiday, Melon Sayli, Uzum Sayli are widespread in Central Asia. It is hard to imagine such public holidays without folk instrument ensembles, singers and musicians, and dancers. Trumpets, trumpets, doira, drums and percussion instruments were widely used in festivals and cultural ceremonies.

At the end of the ninth century, the local feudal dynasty of the Samanids managed to unite a large part of Central Asia. Bukhara, the capital of the Samanid state, became a major cultural center. Literature and music flourished here. Due to changes in living conditions, the social significance of the art of music has increased. The role of music in the lives of urbanites and upper classes has increased significantly. At that time specialization led to the emergence of specialized music workshops There were vocal instrumental music series that included solo, ensemble music, and dance.[3]
One of the peculiarities of the culture of medieval music performance was that instrumentalists not only played several types of musical instruments, but also composed music themselves. The musicians were also mature musicians and poets of their time. Musical in medieval conditions i. Here the teacher-student tradition was settled and developed. At the same time, the ensemble's performance improved, the main forms of musical art were formed, and new samples of musical instruments were discovered.

The theoretical views of Eastern scholars were formed on the basis of existing experience in the performing arts, and in their treatises they provided detailed information about the role and importance of music in society. Farobi's (873950) "Great Book of Music" ("Kitab al-musiqa alkabr"), Abu Ali ibn Sina's (980-1037) "Book of Healing" ("Kitab ush-shifo") encyclopedia , alKhwarizmi's "Key to Knowledge" (10th century), Sayfuddin Urmavi's (1216-1294) "Book of Nobility" or "Book of Sharafiya", Jami's (14141492) "Booklet on Music" about music performance and folk instruments data are described.[4]

Sayfuddin Urmavi is known as a talented oud player, singer, and famous musician. He was born in Urmavia, Azerbaijan. Sayfuddin's greatest achievement was that he developed a perfect system of modes.

Ibn Zayli's (Complete Book on Music) (Kitab ulkabir fil-musiqiy) (died in 1044) is his only and invaluable book in the science of music. He developed a new way of expressing moods in letters in music.

Abdukadir Maroghi (15th century), Abdukadir ibn-Royibi (Maroghi) was born in the city of Marog in Azerbaijan, but spent the second half of his life in the palace of Amir Temur - in Samarkand and died in Herat. In his pamphlet The Collection of Tones in the Science of Music (Jami al-alhan fi-ilm al-musiqiy), he enriched the 
CURRENT RESEARCH JOURNAL OF PEDAGOGICS 2(12): 98-105,

December 2021 DOI: https://doi.org/10.37547/pedagogics-crjp-02-12-20

ISSN 2767-3278

(C)2021 Master Journals

\section{Crossref do) 8 Google}

Accepted 18 $8^{\text {th }}$ December, 2021 \& Published 23 th December, 2021

doctrine of music with information about the existence of a kind of musical instrument, such as the bow, the seven-stringed gijjak.[5]

Al-Husayn's (15th century) pamphlet, The Musical Canons, provides valuable information about a number of musical instruments, the dutar, a two-stringed instrument widely used among the peoples of Central Asia.

Qutbiddin al-Sherazi (1236-1310), known as an Iranian music theorist, spoke of the bowed tanbur in his treatise and considered the human voice to be the most pleasing of musical instruments. Darvish Ali, a 17th-century Bukhara musicologist, gave detailed information about musical instruments such as the tanbur, chang, kanun, rubab, kobiz, and gijjak.

The heritage of the thinkers of the Great East also has historical value in the study of folk instruments. Abu Nasr Muhammad Farabi's famous work "Kitab al-musiqa al-kabir" ("The Great Book of Music") is also of great importance. In this famous book, the medieval scholar distinguishes between two types of musical performance: the restoration of melody in the human voice (the art of singing) and the playing of instruments. As a talented performer, Farobi focuses on the study of the role of musical instruments in public life, and writes:

Farobi's above opinion is that the instruments played a leading role not only among the courtiers, but also among the urban and rural population, cattle-breeders, artisans, as well as in the field of musical culture.

The second part of the book is entirely devoted to the musical instruments of that period. It describes lyutnya, tanbur, nay, rubob, chang, kanun and other musical instruments in a consistent and detailed manner. Pharoah considered the stringed, mizrobly lyutnya to be the most common instrument at that time. Lyutnya is affected by a specific mizrob (click), and on the handle are ligatures (lad). In the IX-X centuries lyutnya took the Arabic name ud. This instrument is still preserved in many Eastern countries, among the peoples of the Caucasus. Samples of modern oud are now stored in the Museum of the National Instrument Laboratory of the State Conservatory of Uzbekistan.[6]

In The Great Book of Music, Farobi describes another instrument, the tanbur. According to the scientist, tanbur (tongue irritation) is one of the closest types of instruments to the oud.

In the tanbur, the strings are pressed using a nail (a special metal click-nail). The tanbur is as common and popular as the oud. The tanbur had two or three brass (wire) strings. Two types are known: the Khorasan and Baghdad tanburs. Baghdad tanburs had fewer maqams (curtains) (five), and the instrument handle was shorter. The Khurasan tanbur had many maqoms (curtains), on the handle of which there were curtains from the throat of the instrument to half of the handle. This type of tanbur has not lost its form to this day and is used in practice as a soloist and ensemble instrument.

Pharoah also describes the flute. One of them is a simple reed or a multi-hole reed located in one direction. This type of flute, or flute of various names, still exists today among the peoples of the East. The Vietnamese call it "sao", the Tajiks "tutek", the Tatars "kaval", the Kazakhs "sibizga", the Azerbaijanis "ney" (very rare), the Kyrgyz "choor" (shepherd's instrument), the Uzbeks "nay" calls. The scientist also mentions a common trumpet, which is often made of mulberry wood.[7]

Farobi also mentions dunay (mizmar). The modern neighboring Danube or Turkmen folk instrument is similar to the Gosha-speaking "tyuy duke" (an instrument made of double reed tubes).

In his treatise, Farobi also describes in detail the 
CURRENT RESEARCH JOURNAL OF PEDAGOGICS 2(12): 98-105,

December 2021 DOI: https://doi.org/10.37547/pedagogics-crjp-02-12-20

ISSN 2767-3278

(C)2021 Master Journals

\section{Crossref do) 81 Google}

Accepted 18 ${ }^{\text {th }}$ December, 2021 \& Published 23 ${ }^{\text {th }}$ December, 2021

rubab that existed during his lifetime. The rubab of that period, like the present Kashgar rubab, consisted of a resonator and a much longer handle. There were two different clickable rubabs. 1 wooden decal and the main part is made of wood, 2 the lower part is made of leather.

Farobi points out that the dust belongs to a series of musical instruments that create a melody through the vibration of open strings. The dust of that period had 15 strings, which were tuned diatonic and had a volume equal to two octaves. All the instruments described in the pamphlet were used to accompany singing, dancing, soloism, and ensemble performance. Farobi testified that the oud played a leading role in the ensemble's performance. In the Book of Musical Instruments, the scholar explains how to tune his instruments, such as the tanbur, rubab, and chang, to fit the melody played by the oud or the soloist. Thus, the great scholar of the East laid the foundations of the field of instrumental studies, which studied instruments as a branch of musicology. This field was later enriched and developed in the works of other scholars as well.

According to the period in which he lived, the great scholar Ibn Sina was very close to Farabi. His major encyclopedia, The Book of Medicine, contains a chapter on music. In these pamphlets, a lot of space is given to the definition of instruments. Ibn Sina divided the music of his time into two groups: mizrobli, nohunli (barbad, tanbur, rubob) and open-stringed instruments (shahruh, chiltor, lyre, chang, harp) drawn along the entire resonator cover.

At that time, the famous thinker of the East, Sayfuddin Urmavi, developed the system of musicology. He was known as a master musician, singer and skilled composer. Based on his experiments in Udda, the scientist stated his theoretical rules. In Urmavi's Book of Piety, the oud is said to be the most popular and most modern of the musical instruments. Ud had five pairs of strings and 7 status (ladi) in the order of a quarter. The strings are called bam, masnas, masna, zir, and the highest hadd. The improved double-stranded oud has retained its structure in recent times. Sherazi (1236-1311), Jami (15th century), al-Husseini, Maraghi, and Ibn Sina also wrote about the five twin strings and seven maqams (ladas) of Ud that were tuned to the quartet. A complete sketch of the oud handle given in Jami's "Musical Booklet" gives a complete picture of its setting. According to the scientist, the existing 12 maqoms are the basis of ancient mature music. Focusing on the impact of community music on listeners, he believes that it has a deep spiritual and spiritual significance.[8]

The pamphlets created in the XIII-XVII centuries give descriptions of stringed instruments such as chang, kanun, nuzkha, rubob, tanbur, as well as descriptions of damli. Darvish Ali's (17th century) Bukhara pamphlet on music can serve as a source of information on traditional instruments. It contains rare information about the culture of music, in particular, the instruments available in the major cities of Central Asia, as well as talented performers.

Darvish Ali's treatise is a valuable source for studying Central Asian music of the 16th and 17th centuries. The play tells the creative biographies of famous singers, musicians and composers. Darwish Ali, like his predecessors, called the udni, which is considered the best among stringed mizrob instruments in terms of its vibrating tone, the "king" of the instruments. According to the pamphlet, it is dedicated to Zuhra, the patron saint of dust instruments.

The described powder had twenty-six strings and seven curtains for the performance of the seven maqoms. In addition, the pamphlet mentions such instruments as law, rubab, kobiz, gijjak, music, ekbon-nay, (damli, leather), ruhavza (six-stringed nokhunli), which is 
CURRENT RESEARCH JOURNAL OF PEDAGOGICS 2(12): 98-105,

December 2021 DOI: https://doi.org/10.37547/pedagogics-crjp-02-12-20

ISSN 2767-3278

(C)2021 Master Journals

\section{Crossref do) 8 Google}

Accepted 18 $8^{\text {th }}$ December, 2021 \& Published 23 th December, 2021

widespread in China. Seven of the instruments described by Darwish Ali, tanbur, chang, kanun, ud, rubab, kobiz, and gijjak, were common instruments at that time.

Darvish Ali's data confirms the idea that in the practice of music, the ensemble originally used stringed and stringed instruments that produced the appropriate calories. The pamphlet mentions the names of the dustman Dilorom, the flute players Abduqadir and Khoja Abu Abdullah, Mawlana Qasimi-Rabbani, Sultan-Ahmadi "crazy" rubabs, brothers Sheikh Abu - Bakri Rabbani and Sheikh Behduchi, wise jurist Sheikh Shamsi Rabbani and many other famous masters.

The testimony of Darvish Ali is also valuable in that most of the instruments he recorded (flute, trumpet, dust, law, rubab, tanbur, gijjak, kobiz, doyra, drum, ud) were used in modern Uzbekistan, Tajikistan and other Central Asian republics, as well as in Azerbaijan. has survived to our day and is improving. For a long time, these musical instruments have a strong place in the cultural life of the Uzbek people and have been widely used in their cultural life. Therefore, it is appropriate to call these instruments Uzbek folk instruments. In the works of Abdul Fazl Boyhaqi (XIV century) the names of stringed mizrobli (rud, barbad, tanbur), tambourine and percussion instruments (trumpet, litavra and drum) are mentioned.

It is known that in the past, the system of writing responses to the works of poets ("nazira") was widely used in Eastern literature. Many "Khamsa" were created in this way. In his epic Sab'ai Sayyar (one of the epics of Hamsa), Navoi reinterpreted the ancient legend of Bahrom Gor. The protagonist is a duster named Dilorom. The poet embodied his instrument as a symbol of music.

Zahriddin Muhammad Babur (1483-1530) admits that Alisher Navoi in his time helped many oud players to show their talents. The names of Uzbek folk instrument performers are mentioned in the Boburnoma. Babur also mentions such talented performers as Shah Kulmi-Gijjaki, Hussein Udi, Khoja Abdullah Marvarid Qanuni. During the Navoi period, the performance of nay, ud, gijjak, kanun, karnay, surnay, drums, doyra, and chang was widespread. They were all used equally in both ensemble performance and solo performance. Dust stood out as a solo instrument. Comparing the data of the written monuments of the XV-XVII centuries, it can be concluded that by this time, the culture of performance on folk instruments in Central Asia has matured. Performers of Uzbek folk instruments have also created their own musical works. At that time, there were skilled chang, ud, gijjak, kanun, nay, tanbur, bulamon performers and mature singers, who formed their own ensembles. Solo performance is also developed.[9]

In his memoirs, Wasifi cites the name of Haji Abdullah Marvarid, a lawmaker who invented a brilliant style. The melodies and songs he composed were popular among the people. Thus, in the fine arts and literary heritage of the XIVXVII centuries there was a rich material confirming the stability of the main types of musical instruments, which have their roots in the distant past.

The pamphlets of Central Asian scholars on music, fiction, and painting allow to some extent to restore some of the broken links in the long chain of historical development of Uzbek folk instruments that have survived to the present day. Hundreds of years have passed, and musical instruments have survived to this day, taking their place in solo, ensemble, and orchestral performance. Restoration and development of the makom genre in the art of music performance In the XVII-XIX centuries no major works with detailed descriptions of instruments were created. This is more due to the growing feudal dispersal. The huge state is divided into 
CURRENT RESEARCH JOURNAL OF PEDAGOGICS 2(12): 98-105,

December 2021 DOI: https://doi.org/10.37547/pedagogics-crjp-02-12-20

ISSN 2767-3278

(C)2021 Master Journals

Crossref doi) 81 Google

Accepted 18 ${ }^{\text {th }}$ December, 2021 \& Published $23^{\text {th }}$ December, 2021

separate khanates (Bukhara, Khiva, Quqon khanates). This was reflected in the development of the art of music. Uzbek music culture began to acquire local features. Unique musical instruments were formed. From the types of music - maqoms have since developed in a specific direction in each khanate. Status executors made changes as needed. Nevertheless, they retained the general characteristics of music. Each performer took a creative approach to the performance of the maqom, adding unique aspects to the performance of the music. The tradition of preserving musical instruments orally is one of the main features of the status quo, without which it is difficult to imagine its survival and final development. In each khanate new types of folk music were created in a specific direction; festive, melodies, folk spectacle melodies (dorbozlik, puppetry) new type of dance melodies. These melodies differed from each other by their cheerfulness and joy and attracted a wide audience.

In the late seventeenth and early nineteenth centuries, the following new types of folk and professional music began to develop in Uzbek musical culture; big song, big game, Shodiyona, Navruz, Mavrigi, Shashmaqom, Chor maqom (it included Dugoh, Husseini, Chorgoh, Bayot, Gulyori-Shahnoz). Different musical ensembles have been formed depending on the available musical instruments and performers. In many cases, the ensemble of folk instruments includes musical instruments such as gijjak, tanbur, dutor, chang, nay, koshnay, doira.

Shashmaqom, which consists of six series of works in music, was especially popular. It is the result of the long development of professional music in the form of suites (series) of the peoples of Central Asia. I.Rajabov writes: Shashmaqom consists of six different systems of fret, each of which, in turn, is divided into the following maqoms (parts), consisting of sections of mushkilot (instrument) and prose (ashula):

"Rost", "Buzrug", "Navo", "Dugoh", "Segoh", "Iraq" ... Each status contains 20 to 40 large and small parts. In total, there are about 250 pieces of prose and prose in the category. The execution of one status lasted several hours. Folk instruments develop in close connection with folk oral art and classical literature. Perceptions of folk instruments are enriched by the expressions of musical instruments in works of art, the image of musicians in book miniatures. The names of more than 60 folk instruments are mentioned in the works of Firdavsi, Saadi, Navoi, Dehlavi. The ceremonies were performed mainly in the presence of palace dignitaries at a specific time or under certain conditions. It is even known that a special competition of talented singers was organized (especially in the performance of peaks, as well as in the weaving of unique new parts). The revival and development of the makom genre in the art of music performance continued. The status was inextricably linked with folk songs according to its laws of melody and rhythm, and differed only in the breadth of its scope. Typically, each status is divided into two major parts.

The first is the part that is only performed on the instruments and is called the difficulty, and the second is the part that is sung with the instruments and is called the prose. Nasr also included dance tunes.[10]

Among the musicians, there was an attempt to create a notation system with a special character system that recorded the sounds of the music. The poet-musician Pahlavon Niyaz Mirzaboshi (Komil Khorezmi 1825-1879) was able to do this. Talented musician Pakhlavon Niyaz Mirzaboshi, a skilled drummer and drummer, was amazed to see musicians playing music on the notes during the trip. As soon as Mirzaboshi-Kamil Khorezmi returned to Khorezm, he began to write down his intentions with inspiration. 
CURRENT RESEARCH JOURNAL OF PEDAGOGICS 2(12): 98-105,

December 2021 DOI: https://doi.org/10.37547/pedagogics-crjp-02-12-20

ISSN 2767-3278

(C)2021 Master Journals

Crossref di) 81 Google

Accepted 18 ${ }^{\text {th }}$ December, 2021 \& Published $23^{\text {th }}$ December, 2021

Muhammad Yakub Kharratov (1867-1939), a student of Pakhlovon Niyaz Mirzaboshi Kamil, was a famous drummer. He had mastered not only the art of painting, but also the art of calligraphy. Muhammad Yakub Kharratov (Matyokub Kharratov), a musician of the palace folk instruments ensemble led by the talented musician Kamil Khorezmi, took part in composing the tanbur notation and recording Khorezmian maqoms. He received Khorezmian maqom series from his teacher and made a great contribution to their preservation.

The creative and performing activity of the famous tanbur player and singer Niyazkhoja Haji, who worked in the palace of Muhammad Rahimkhan (1806-1825), took place in Khiva. He paid great attention to Khorezmian musical culture.

According to Matyokub Kharratov, Niyazkhoja went to Bukhara to study Shashmaqom. When he returned from Bukhara, the Bukhara maqoms were mastered by Khiva musicians and began to spread in Khorezm. Famous Khorezm musicians Muhammadrahim Feruz, Kamil Khorezmi, Mirzo Muhammadrasul and others, in cooperation with Niyazkhoja, added new musical instruments to the maqoms and enriched them.

In the second half of the 19th century, the city of Kokand became a gathering place for famous musicians. Here, under the leadership of Master Khudoiberdi, a unique school was created to study the school of performance in Uzbek folk instruments. Fergana instruments began to actively master the Bukhara shashmaqom. His father, Jaloliddin Nosirov (1845-1928), was a maqom performer, a well-known teacher, a musician, and a master drummer. He first learned the science of music from his mother, and then from his father, who was a brilliant scholar of the maqams and a skilled performer. For many years, Ota Jalol Nosirov was the permanent leader and singer of the ensemble of
Uzbek folk instruments in the palace of Amir Alimkhan (Bukhara), Amir Muzaffarkhan (Shahrisabz), Amir Otajonlar (Karmana, now Navoi). he was a scholar, a drummer from Bukhara.

Hoji Abdulaziz Rasulov (1852-1936) was one of the famous performers of Uzbek and Tajik music, a student of the talented tanbur player Hoji Rahimkul. In 1888 he went to Bukhara. There, under the leadership of Ota-Jaloliddin Nazirov, he studied Shashmaqom perfectly for a year. Rasulov actively promoted Uzbek folk music and status in Fergana, Samarkand and Tashkent. He made a significant contribution to the development of Uzbek folk instruments as a tanbur player, dutar player and singer, and won the love of the people and the music community.

The musicians mentioned above began their careers and developed creatively in their time. They were all enlighteners, teachers of young musicians. Their pedagogical views and teachings are a new pedagogical source of performance in Uzbek folk instruments and are preserved as an immortal heritage.

\section{REFERENCES}

1. Alimov F. Uzbek Folk Instrument Orchestra. Tashkent, "Music", 2004.- P.15

2. Dadamuxamedov A. Rubob prima textbook. Tashkent, 2004. - P.10

3. Ergashev G. Afghan rubobi textbook. Tashkent, 2004. - P.64

4. Nurmatov X. Kashgar rubobi. Tashkent, 2003. - P.86

5. Toirov M., Petrosyants A. Musical instruments - "Nay". Tashkent, 2002. P.24

6. Odilov A., Lutfullaev A. Musical instruments - "Dust". Tashkent, 2002. - 
CURRENT RESEARCH JOURNAL OF PEDAGOGICS 2(12): 98-105,

December 2021 DOI: https://doi.org/10.37547/pedagogics-crjp-02-12-20

ISSN 2767-3278

(C)2021 Master Journals

Crossref doi) 81 Google

Accepted 18 ${ }^{\text {th }}$ December, $2021 \&$ Published 23 $3^{\text {th }}$ December, 2021

\section{P.5}

7. Qosimov R. Musical instruments - "Ud". Tashkent, 2002. - P.46

8. Qosimov R. Traditional tanbur performance. Tashkent, 2002. - P.15

9. Ikromov I. Circle textbook. Tashkent, 1997. - P.36

10. Toshmuxamedov M. Gijjak textbook. Tashkent, 1996. - P.77 